\title{
Synthesis of C1 Inhibitor in Fibroblasts from Patients with Type I and Type II Hereditary Angioneurotic Edema
}

\author{
Judit Kramer, ${ }^{*}$ Yitzhak Katz,“ Fred S. Rosen, ${ }^{\star}$ Alvin E. Davis III,* and Robert C. Strunk* \\ *Divisions of Pulmonary Medicine and Allergy/Immunology, St. Louis Children's Hospital, and the Department of Pediatrics, \\ Washington University School of Medicine, St. Louis, Missouri 63110; and ${ }^{\ddagger}$ Divisions of Immunology and Nephrology, The Children's \\ Hospital, the Department of Pediatrics, and the Center for Blood Research, Harvard Medical School, Boston, Massachusetts 02115
}

\begin{abstract}
Patients with hereditary angioneurotic edema (HANE) have serum levels of functionally active inhibitor of the first component of complement (C1 INH) between 5 and 30\% of normal, instead of the $50 \%$ expected from the single normal allele. Increases in rates of catabolism have been documented in patients with HANE and certainly account for some of decrease in $\mathrm{C1}$ INH level. A possible role for a decrease in synthesis of $\mathrm{Cl}$ INH in producing serum levels of $\mathrm{C1}$ INH below the expected $50 \%$ of normal has not been well studied. We studied the synthesis of $\mathrm{Cl}$ INH in skin fibroblast lines, which produce easily detectable amounts of $\mathrm{C} 1$ INH. In type I HANE cells, C1 INH synthesis was $19.6 \pm 4.0 \%$ (mean \pm SD) of normal, much less than the $50 \%$ predicted. In type II HANE cells, the total amount of $\mathrm{Cl}$ INH synthesis (functional and dysfunctional) was $98.9 \pm 17 \%$ of normal; the functional protein comprised $43 \%$ of the total. Thus, type II HANE cells synthesized functional C1 INH at a much greater rate than for the type I cells. In both type I and II HANE cells, amounts of steady-state C1 INH mRNA levels paralleled rates of $\mathrm{C} 1$ INH synthesis, indicating that control of $\mathrm{C} 1$ INH synthesis occurred at pretranslational levels. Both type I and type II fibroblasts synthesized normal amounts of $\mathrm{C1r}$ and $\mathrm{C1s}$. These data suggest that the lower than expected amounts of functionally active $\mathrm{Cl}$ INH in type I HANE may be due, in part, to a decrease in rate of synthesis of the protein, and that the expressions of the normal $\mathrm{Cl}$ INH allele in HANE is influenced by the type of abnormal allele present. (J. Clin. Invest. 1991.87:1614-1620.) Key words: synthesis of $\mathrm{Cl}$ inhibitor $\bullet$ hereditary angioneurotic edema
\end{abstract}

\section{Introduction}

Hereditary angioneurotic edema (HANE) ${ }^{1}$ is an autosomal dominant disorder due to a deficiency of the inhibitor of the first component of complement ( $\mathrm{Cl}$ INH). Patients with HANE have serum levels of functionally active $\mathrm{Cl}$ INH between 5 and $30 \%$ of normal, instead of the $50 \%$ expected from

Address reprint requests to Dr. Robert C. Strunk, Children's Hospital, Washington University School of Medicine, 400 South Kingshighway Boulevard, St. Louis, MO 63110.

Received for publication 7 June 1990 and in revised form 13 December 1990.

1. Abbreviations used in this paper: $\mathrm{C} 1 \mathrm{INH}$, inhibitor of the first component of complement; HANE, hereditary angioneurotic edema.

J. Clin. Invest.

(C) The American Society for Clinical Investigation, Inc.

0021-9738/91/05/1614/07 \$2.00

Volume 87, May 1991, 1614-1620 the single normal allele. Lachmann and Rosen suggested that the reduction below the expected serum level is due to catabolic behavior of $\mathrm{Cl} \mathrm{INH}$, in which a level of $50 \%$ of normal cannot be maintained due to consumption of $\mathrm{Cl}$ INH during its reaction with proteinases (1). Analysis of the metabolism of $\mathrm{Cl}$ INH in HANE patients was consistent with this hypothesis, with an elevation of the fractional catabolic rate from 0.025 of the plasma pool/h in normals to 0.035 in patients with HANE (2).

A possible role for a decrease in synthesis of $\mathrm{C} 1 \mathrm{INH}$ in producing serum levels of the protein below the expected $50 \%$ of normal has not been well studied. The most definitive information on the involvement of the rate of synthesis would come from study of hepatocytes, which are probably the major source of the plasma protein. However, these cells are unavailable for study because of both ethical and technical considerations. As an alternative to the study of $\mathrm{C} 1 \mathrm{INH}$ in hepatocytes, some investigators have used peripheral blood monocytes, which also produce $\mathrm{Cl}$ INH. Cicardi et al. studied monocytes from three type I HANE patients and documented synthesis rates by metabolic labeling of the cells with $\left[{ }^{35} \mathrm{~S}\right]$ methionine (3). The intracellular C1 INH levels were 43,53 , and $35 \%$ of normal controls (3). Lappin et al. studied monocytes from eight patients and documented production of $\mathrm{Cl}$ INH by measurement of the protein in a 7-d supernatant with an ELISA (4). Cells from seven of the patients produced $\mathrm{C} 1 \mathrm{INH}$ with a mean value $\sim 40 \%$ of the amount produced in normal cells. Cells from one patient produced no $\mathrm{Cl} \mathrm{INH}$, unless stimulated with gamma-IFN. Unfortunately, studies of synthesis of $\mathrm{Cl}$ INH in monocytes from HANE patients cannot provide an exact comparison between amounts of the protein synthesized in HANE and control cells because the rate of synthesis of $\mathrm{Cl}$ INH in monocytes is low, even in normal cells. Another approach to the study of the rate of synthesis of C1 INH in HANE patients is to infer rates of synthesis of $\mathrm{Cl} \mathrm{INH}$ in studies of turnover of radiolabeled $\mathrm{Cl} \mathrm{INH}$. Two patients, both with type I HANE, have been studied using this approach. Synthesis rates were calculated to be 32 and $28 \%$ of normal (2).

Because of the implications for study of the molecular mechanisms of HANE, defining possible alterations in the functioning of the single normal $\mathrm{Cl}$ INH gene in HANE is essential. Since both methods used previously to define rates of synthesis of $\mathrm{C} 1 \mathrm{INH}$ in HANE have had distinct disadvantages, we have used fibroblast cell lines derived from patients with HANE. The use of fibroblasts has the advantage that the amount of $\mathrm{Cl}$ INH synthesized in fibroblasts is $50-100$ times greater per cell than in monocytes $(5,6)$, and that fibroblasts are replicating cells, with multiple experiments possible from a single skin biopsy from a patient. In addition, synthesis of $\mathrm{Cl}$ INH in fibroblasts appears to be regulated in a similar manner to synthesis in other primary human cell cultures, in that syn- 
thesis of the protein is increased primarily by IFN- $\gamma$ in the three types of primary human cells studied in culture, monocytes (7), endothelial cells (8), and fibroblasts (6). Cells were studied from patients with type I HANE, who have low $\mathrm{Cl}$ INH function and protein present in serum, and type II HANE, who have normal or elevated levels of the protein, but low $\mathrm{Cl}$ INH function (9-12). The type II kindred chosen for study have a dysfunctional $\mathrm{C} 1 \mathrm{INH}$ that can be distinguished from the normal protein in SDS-PAGE (11-13), so that rates of synthesis and secretion of both the normal and dysfunctional proteins could be measured.

\section{Methods}

Cells. Normal human adult skin fibroblast lines were obtained from Human Genetic Mutant Cells, National Institute of General Medical Sciences, Camden, NJ, from Department of Dermatology, Washington University School of Medicine, St. Louis, MO, or were propagated in our laboratory by standard techniques. Fibroblast lines were also been started from skin biopsies obtained from type I and type II HANE patients. The four type I HANE patients (three females and one male from four different kindred) had well defined disease with family history of angioedema and amounts of serum $\mathrm{Cl}$ INH protein well below the normal range. The type II HANE patients (one individual from the Ta kindred and two individuals of We kindred, designated Wel and We2) have already been described $(9,11-13)$ (all these subjects were males). The $\mathrm{Ta}$ and We kindreds were chosen for study because the dysfunctional $\mathrm{Cl}$ INH of these patients could be distinguished from normal in SDS-PAGE analysis. Cells from passages 4-8 were used in experiments.

Reagents. DMEM, low endotoxin, fetal bovine serum (FBS) (endotoxin $<0.01 \mathrm{ng} / \mathrm{ml}$ ), and DMEM without methionine were purchased from Gibco Laboratories, Grand Island, NY, and penicillin-streptomycin solution and L-glutamine from Flow Laboratories, Inc., McLean, VA. BSA, fraction V (low endotoxin), was purchased from Sigma Chemical Co., St. Louis, MO. L- $\left[{ }^{35}\right.$ S $]$ methionine (sp act $\sim 1,000$ $\mathrm{Ci} / \mathrm{mmol}$ ) was purchased from ICN Biochemicals Inc., Irvine, $\mathrm{CA}$, and $\mathrm{En}^{3} \mathrm{Hance}$ from New England Nuclear, Boston, MA. Goat antibodies to human $\mathrm{Cl}$ INH and to $\mathrm{C} 1 \mathrm{r}$ were purchased from Atlantic Antibodies, Scarborough, ME, and to human C1s from Cytotech, San Diego, CA. Formalin-fixed Staphylococcus aureus (Immunoprecipitin) was purchased from Bethesda Research Laboratories Life Technologies, Inc., Gaithersburg, MD. PMSF was purchased from Sigma Chemical Co. and leupeptin from Calbiochem-Behring Corp., La Jolla, CA. IFN$\gamma$ was the generous gift of Dr. Peter F. Sorter, Hoffman-La Roche Inc., Nutley, NJ. Purified activated C1s was obtained from Dr. David Bing, Center for Blood Research, Boston, MA; the material contained a single protein with two chains under reducing conditions, C1sA $(\sim 58$ $\mathrm{kD}$ ) and C1sB ( $28 \mathrm{kD})$. Horseradish peroxidase (type VIA), sodium borohydride, and sodium m-periodate were purchased from Sigma for peroxidase conjugation.

Cell cultures, biosynthetic labeling, and immunoprecipitation. $\mathrm{Hu}-$ man fibroblasts were grown to confluency in multiwell tissue culture plates in medium containing 10\% FBS and then washed to remove serum and spent medium. The cells were either labeled biosynthetically immediately after removal of the FBS or after being stimulated overnight with IFN- $\gamma(1,000 \mathrm{U} / \mathrm{ml})$ in DMEM containing $0.1 \%$ BSA. Biosynthetic labeling was performed by incubating the cells in methioninefree DMEM containing $250 \mu \mathrm{Ci} / \mathrm{ml}\left[{ }^{35} \mathrm{~S}\right]$ methionine $(14,15)$ for periods ranging from $60 \mathrm{~min}$ to $4 \mathrm{~h}$. The 60 -min pulse period was used to quantitate synthesis rates since there was no, or only minimal, secretion of newly synthesized proteins during this period. The number of cells adherent at confluency did not vary with the type of cells and was not affected by treatment with IFN- $\gamma$. The number of cells in each 16 - $\mathrm{mm}$ well was $9.78 \times 10^{4} \pm 0.38($ mean $\pm \mathrm{SD})$. At the end of the pulse period, cells were rinsed and either lysed by freeze thawing as previously described (14), or in pulse-chase experiments, medium containing $\sim 1,000$-fold excess of cold methionine (DMEM containing $10 \%$ FBS) was added, and the cells were incubated for varying time periods (chase periods). Cell lysates and extracellular media were prepared for immunoprecipitation by adding PMSF and leupeptin as enzyme inhibitors and detergent (SDS, DOC, Triton-X 100), preabsorbed, and then immunoprecipitated with monospecific antibodies using formalin-fixed $S$. aureus (14). Immunoprecipitates were subjected to SDS-PAGE under reducing conditions, and the gels were fixed, impregnated with $\mathrm{En}^{3} \mathrm{Hance}$, dried, and exposed at $-70^{\circ} \mathrm{C}$ to Kodak XAR-5 film. Total protein synthesis was estimated by incorporation of $\left[{ }^{35}\right.$ S]methionine into TCA-insoluble protein (14). Incorporation of $\left[{ }^{35}\right.$ S $]$ methionine into individually immunoprecipitated proteins was determined by subtracting the appropriate background from the counts in the portion of the gel slices containing the protein after digestion with $15 \%$ hydrogen peroxide for $16 \mathrm{~h}$ at $65^{\circ} \mathrm{C}$ and addition of Bio-Safe II (Research Products International Corp., Mount Prospect, IL) (16). Background counts were obtained in another portion of the appropriate lane of the gel not containing protein.

Calculation of the amount of protein synthesized. The cells kept in DMEM plus $10 \%$ FBS until reaching confluency were pulse labeled for $60 \mathrm{~min}$. Cell lysates were immunoprecipitated sequentially for $\mathrm{Cl}$ $\mathrm{INH}, \mathrm{Cl}$, and $\mathrm{Cls}$. The total $\left[{ }^{35} \mathrm{~S}\right]$ methionine incorporation into TCAinsoluble proteins varied up to twofold not only among different cell lines, but also from experiment to experiment for a single cell line. Possible reasons for this variability included the specific activity of the $\left[{ }^{35} \mathrm{~S}\right]$ methionine used and differences in the time the cells were confluent before being studied (cells confluent for longer periods of time seemed to have lower total protein synthesis). Because of this variability, the amounts of specific proteins were corrected for the total incorporation into TCA-insoluble proteins in the same experiment. Based on this calculation, $\mathrm{Cl} \mathrm{INH} /$ total synthesized proteins (mean $\pm \mathrm{SD}$ ) in one particular experiment with six replicates for each cell type were $1.09 \pm 0.11 \times 10^{-4}, 0.22 \pm 0.04 \times 10^{-4}$, and $1.32 \pm 0.33 \times 10^{-4}$ for normal, type I, and type II, respectively.

Densitometric scanning of autoradiograms. The autoradiograms were scanned using a laser densitometer (Ultroscan XL; LKB Instruments, Inc., Gaithersburg, MD). The front lines of the gels were adjusted to be completely horizontal. The densitometer was programmed to scan each line of the gel between the same distances from the front line, allowing placement of all the densitograms from the same autoradiogram on the same graph.

Determination of secreted CI INH by ELISA. After reaching confluency, the cells were washed and spent media were replaced by fresh DMEM containing 10\% FBS. 24-h supernatants were collected and the secreted $\mathrm{Cl}$ INH was detected by sandwich enzyme-linked immunoassay (17) using peroxidase-conjugated polyclonal anti-human $\mathrm{Cl}$ INH antibody.

Binding of Cl INH to activated Cls. Extracellular media obtained after $4 \mathrm{~h}$ of pulse with $\left.{ }^{35} \mathrm{~S}\right]$ methionine were collected without added enzyme inhibitors at $4^{\circ} \mathrm{C}$, spun at $0^{\circ} \mathrm{C}$ for $20 \mathrm{~min}$ to remove cellular debris, and stored at $-70^{\circ} \mathrm{C}$ until used. Aliquots of these media were incubated for $1 \mathrm{~h}$ at $37^{\circ} \mathrm{C}$ with medium alone (control) or with different concentrations of activated Cls. After the incubation period, a mixture of the enzyme inhibitors and detergents (14) was added to prepare samples for immunoprecipitation. The samples were immunoprecipitated for $\mathrm{C} 1 \mathrm{INH}$.

RNA extraction and Northern blot analysis. Total cellular RNA was extracted from fibroblast monolayers of different types of cells by lysis with guanidinium thiocyanate and isolated by cesium chloride density gradient ultracentrifugation, as described previously (18). Recovery of RNA, which was similar for the different cell lines, was not affected by the IFN- $\gamma$ treatment. $10 \mu$ g total cellular RNA was subjected to Northern blot analysis using a double-stranded cDNA probe for human $\mathrm{Cl}$ inhibitor radiolabeled with ${ }^{32} \mathrm{P}$ by nick translation. The probe was $1.227 \mathrm{~kb}$, corresponding to nucleotides from 554 to 1780 (19). 


\section{Results}

Rate of synthesis of CI INH in types I and II HANE fibroblasts. Radiolabeled, newly synthesized intracellular C1 INH proteins were detected in normal and types I and II HANE fibroblast cell lines (Fig. 1). Under reducing conditions, the apparent $M_{\mathrm{r}}$ of the intracellular C1 INH in normal and type I HANE cells was $78 \mathrm{kD}$. The type II HANE cells also contained the $78-\mathrm{kD}$ C1 INH, but had an additional $86-\mathrm{kD}$ form (Fig. 1 shows the results with the Ta cell line). The 78 and $86-\mathrm{kD}$ proteins were also present in the cells from the We kindred (data not shown), although previous data suggest that the mutation in the Ta and We kindreds is different $(9,11,13)$.

To determine the rates of synthesis of $\mathrm{Cl} \mathrm{INH}, \mathrm{Clr}$, and $\mathrm{C} 1 \mathrm{~s}$ in different cell types, cell lysates after $1-\mathrm{h}$ pulse periods were immunoprecipitated sequentially for the three proteins. The amounts of newly synthesized $\mathrm{Cl} \mathrm{INH}$, as well as $\mathrm{Cl} \mathrm{r}$ and C1s, are shown in Figure 2 and Table I. The numbers correspond to three to five experiments with each patient's cell line and three to six experiments with each of six different control cell lines. For the normal cell lines, $\mathrm{C} 1 \mathrm{INH} /$ total synthesized proteins ranged from 0.40 to $2.00 \times 10^{-4}$, with the mean $\pm S D$ equal to $0.91 \pm 0.39 \times 10^{-4}$. For type I HANE, mean rates of synthesis of $\mathrm{Cl} \mathrm{INH}$ in the four lines were $14 \pm 8 \%, 22 \pm 7 \%$, $24 \pm 4 \%$, and $23 \pm 8 \%$ of the normal mean rate.

In type II HANE, mean rates of synthesis for the combination of the 78 and $86-\mathrm{kD}$ forms of $\mathrm{Cl}$ INH were $107 \pm 41 \%$, $118 \pm 28 \%$, and $79 \pm 33 \%$ of the normal mean rate, for the $\mathrm{Ta}$, We1, and We2 lines, respectively. Relative amounts of the functional (78 kD) and dysfunctional (86 kD) forms of C1 INH synthesized were estimated by soft laser densitometry of autoradiographs of $\mathrm{Cl}$ INH precipitated from intracellular lysates after 1-h pulse periods (such as the one shown in Fig. 3, intracellular lane 1 ). The functional band comprised $37 \pm 2 \%$ for $\mathrm{Ta}$, $44 \pm 1 \%$ for $W e 1$, and $46 \pm 3$ for We2, of the total amounts of $C 1$ INH synthesized by the cells. When these percentages were compared to the total amounts of $\mathrm{Cl}$ INH synthesized relative to normal, the amounts of functional protein synthesized by the three type II cell lines were 40,52 , and $36 \%$ of that synthesized in the normal lines (mean $=43 \%$ ). Thus, the functional C1 INH synthesized in type II cells (43\% of normal) was much

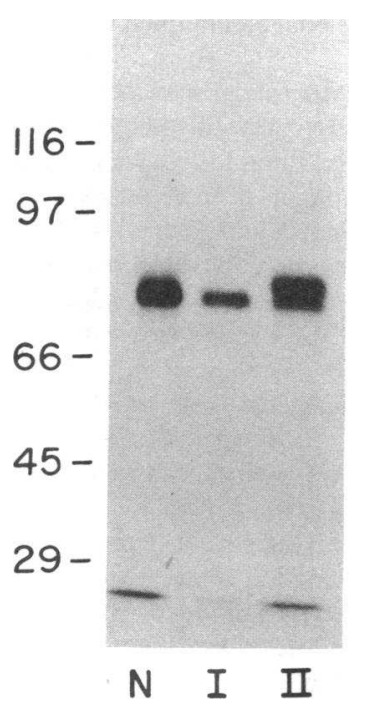

Figure 1. Synthesis of $\mathrm{C} 1 \mathrm{INH}$ in normal and types I and II HANE fibroblasts. An autoradiograph of SDSPAGE analysis under reducing conditions is shown. The fibroblasts were grown to confluence in DMEM plus $10 \% \mathrm{FBS}$, washed to remove spent medium and serum, and pulse labeled with $\left[{ }^{35} \mathrm{~S}\right]$ methionine, $250 \mu \mathrm{Ci} / \mathrm{ml}$, for $2 \mathrm{~h}$. The cell lysates were immunoprecipitated with monospecific antibodies for $\mathrm{C} 1 \mathrm{INH}$ and $S$. aureus, as described in Methods.

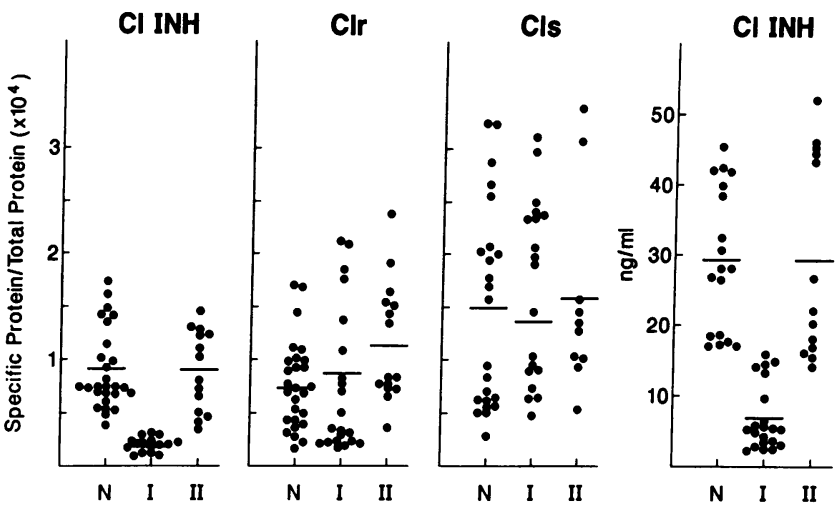

Figure 2. Quantitation of $\mathrm{C} 1 \mathrm{INH}, \mathrm{Clr}$, and $\mathrm{C} 1 \mathrm{~s}$ proteins. In the three panels on the left, synthesis of $\mathrm{Cl} I N H, C 1 r$, and $\mathrm{Cls}$ proteins was quantitated by measurement of $\left[{ }^{35} \mathrm{~S}\right]$ methionine incorporated into the proteins in a 1-h pulse period. The radiochemically labeled proteins synthesized by the fibroblasts were sequentially immunoprecipitated, as described in Methods. After autoradiography, the bands corresponding to the specific proteins were cut from the gel, digested, and counted. The ordinate represents specific protein counts minus appropriate background counts divided by the total TCA insoluble $\left[{ }^{35} \mathrm{~S}\right]-$ methionine-labeled protein in the same experiment.

In the panel on the right, $\mathrm{C} 1 \mathrm{INH}$ in supernatants of cells cultured for $24 \mathrm{~h}$ with fresh DMEM plus 10\% FBS was detected by ELISA, as described in Methods.

higher than in type I cells ( $20 \%$ of normal), suggesting that the expression of the normal allele is influenced by the type of mutant allele present.

Synthesis of $\mathrm{Cl} \mathrm{r}$ and $\mathrm{Cls}$ was comparable in normal and types I and II cells (Fig. 2). Both C1r and C1s were present only

Table I. C1 INH, C1r, and C1s Produced by Normal and Types I and II HANE Fibroblast Cell Lines

\begin{tabular}{llcc}
\hline \multicolumn{2}{c}{ Synthesized proteins } & $\begin{array}{c}\text { Specific protein/ } \\
\text { total protein }\end{array}$ & $P$ value \\
\hline \multirow{4}{*}{ C1 INH } & Mean $( \pm S D) \times 10^{\circ}$ & \\
& Normal & $0.91(0.39)$ & - \\
& Type I & $0.18(0.07)$ & $P<0.001$ \\
& Type II & $0.90(0.38)$ & NS \\
C1r & Normal & $0.73(0.43)$ & - \\
& Type I & $0.87(0.69)$ & NS \\
& Type II & $1.13(0.56)$ & $P=0.04$ \\
C1s & Normal & $1.49(0.96)$ & - \\
& Type I & $1.36(0.85)$ & NS \\
& Type II & $1.58(0.93)$ & NS \\
& & $n g$ Cl INH/ml medium & \\
Secreted protein & Mean $( \pm S D)$ & - \\
& Normal & $29.3(9.9)$ & NS \\
C1 INH & Type I & $6.9(4.5)$ & \\
& Type II & $29.2(13.9)$ & \\
& & &
\end{tabular}

Statistical analyses of the results shown in Fig. 2. The amounts of the protein in the type I and II HANE fibroblasts were compared to normal using two-tailed Student's $t$ test. 

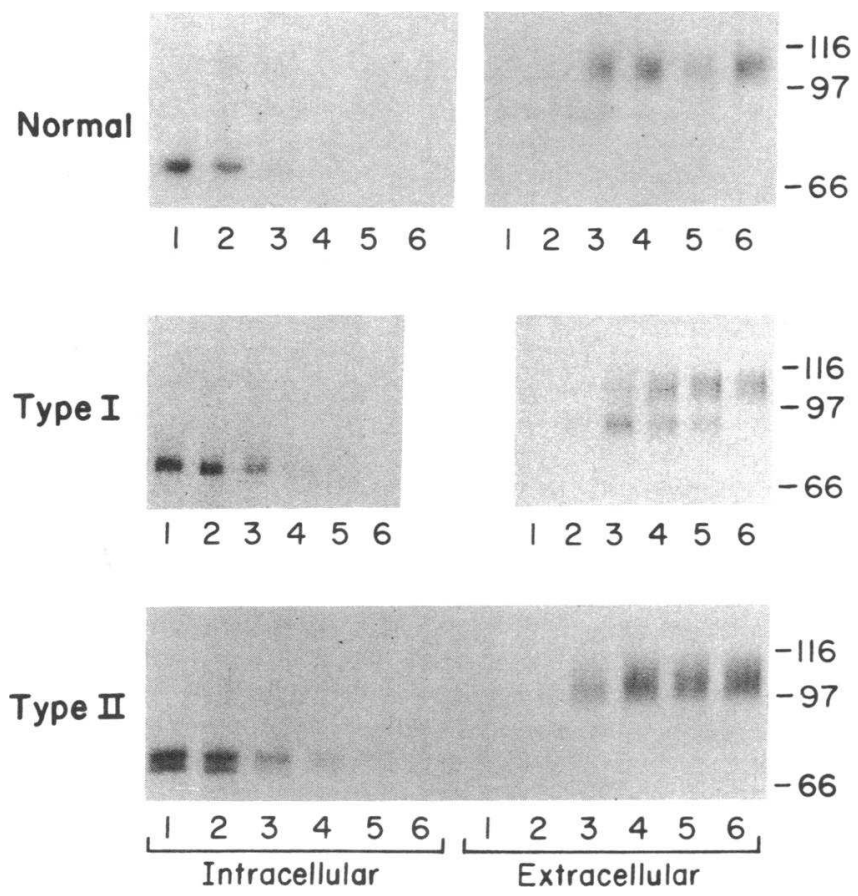

Figure 3. Secretion of $\mathrm{C} 1 \mathrm{INH}$ : pulse-chase experiments. Normal, type I, and type II HANE fibroblasts were pulse labeled for $1 \mathrm{~h}$ and then the labeled proteins were chased with DMEM plus $10 \%$ FBS. At different time points, cells and media were harvested and $\mathrm{C} 1 \mathrm{INH}$ was immunoprecipitated from intracellular lysates (left) and extracellular media (right). The time points were as follows: $1-0 \mathrm{~h} ; 2-1.5 \mathrm{~h}$; 3-3 h; 4-5 h; and 6-20 h after the pulse. The intensities of the bands in the three types of cells are almost the same due to different exposure periods of the autoradiographs. The molecular mass markers in kilodaltons are shown on the right side of each panel.

in their zymogen forms, i.e., only single bands were present even when the autoradiograms were overexposed (data not shown). Incubation of the medium up to $24 \mathrm{~h}$ did not result in appearance of activated forms of $\mathrm{Clr}$ or $\mathrm{Cls}$, or the formation of a complex between $\mathrm{C} 1$ INH and C1s (data not shown).

Rate of secretion of CI INH from type I and II HANE fibroblasts. In the extracellular media from the normal cells, the major form of $\mathrm{Cl}$ INH was present at $\sim 102 \mathrm{kD}$, corresponding to the protein present in normal serum (Fig. 3, lane 6 of the extracellular samples). For type I cells, the major extracellular form was also $102 \mathrm{kD}$, whereas for type II cells the extracellular form was more diffuse than for normal or type I cells (Fig. 3). C1 INH secreted from the Ta cells had broader molecular mass, up to $\sim 110 \mathrm{kD}$, consistent with the characteristics of the protein purified from serum. The difference in the extracellular C1 INH was more apparent for Ta than for We (data not shown)

In the extracellular media of the type I and type II cells there was an additional band at $94 \mathrm{kD}$ in almost every experiment (e.g., Fig. 6, lanes 1 for type I and type II). This band was also present with normal cells in some experiments, although it was always much less prominent than with the HANE cells (e.g., Fig. 6, lane 1 for normal).

The rate of secretion of $\mathrm{Cl}$ INH from the different types of cells was determined by quantitation of the amounts of $\mathrm{Cl}$ INH protein at the various times in the pulse-chase experi- ments, such as the one shown in Fig. 3. For the type I cells, the secretion of $\mathrm{Cl}$ INH paralleled exactly the secretion from the normal cells (Fig. 4). The accumulation of the secreted $\mathrm{C} 1 \mathrm{INH}$ in the supernatants during $24 \mathrm{~h}$ of culture is shown in Fig. 2 (right) and Table I. C1 INH secreted by type I cells in a 24-h period was $23 \%$ of normal, similar to the amount detected intracellularly.

For the type II cells, the accumulation of $\mathrm{Cl}$ INH in the supernatants was $100 \%$ of normal, similar to the amount detected intracellularly. The pattern of secretion of $\mathrm{C} 1 \mathrm{INH}$ did show a subtle difference from that of normal and type I cells, in that the $86-\mathrm{kD}$ form was secreted more slowly than the $78-\mathrm{kD}$ form. This difference was apparent in the pattern of secretion from the Ta type II cells shown in Fig. 3, where the 86-kD form persists in the type II cells through $5 \mathrm{~h}$ and the $78-\mathrm{kD}$ form is almost completely secreted by $3 \mathrm{~h}$ (the same pattern was apparent for the We lines; these data are not shown). The differential rates of secretion of the 78 and $86-\mathrm{kD}$ forms of the protein were also apparent in the densitometric scanning of the autoradiograms of the pulse-chase experiment using the Ta fibroblast line, where the abnormal protein could be most clearly distinguished from the normal (Fig. 5). The band present in these type II cells after $1.5 \mathrm{~h}$ had a peak similar in mass to the band in the normal (the asymmetry of the band at this time indicated that some of the higher mass protein had also been secreted). With increasing time of chase, the peak shifted toward a higher molecular mass.

Binding of Cl INH to activated C1s. To determine whether C1 INH synthesized by the type I and II HANE fibroblasts was functionally active, supernatants of different, radiochemically labeled fibroblast cultures were incubated with purified activated $\mathrm{Cls}$ and immunoprecipitated for $\mathrm{Cl}$ INH. As the amount of activated $\mathrm{Cls}$ added to the supernatants increased, the 102-kD form of $\mathrm{C} 1 \mathrm{INH}$ decreased and a band appeared at $125 \mathrm{kD}$, representing the complex between $\mathrm{C} 1 \mathrm{INH}$ and $\mathrm{Cls}$

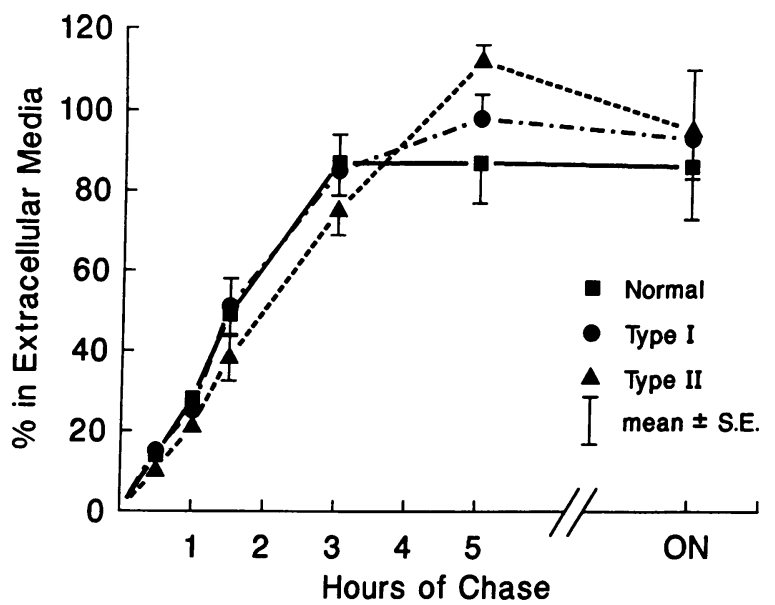

Figure 4. Rates of secretion of $\mathrm{Cl}$ INH. Four separate pulse-chase experiments for each type of cell were analyzed. Amounts of protein present in the intracellular lysate after 1-h pulse and in the extracellular media at each time of chase were quantitated, as described in the legend for Fig. 2. The ordinate represents the amount of extracellular C1 INH divided by the amount in the cell lysate after the 1-h pulse. For the type II cells, the data represent the combination of the normal and dysfunctional forms of the protein. 


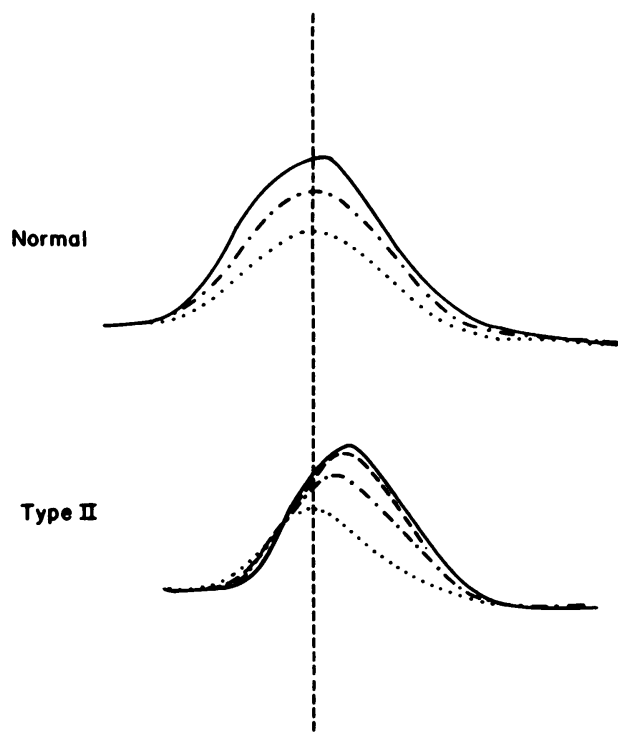

Figure 5. Densitograms of the secreted C1 INH in normal and type II HANE fibroblasts. The bands of extracellular C1 INH on the autoradiograms obtained at various times of the chase (Fig. 3) were scanned by LKB Ultroscan XL laser densitometer. The molecular mass increases from left to right. ( . ) $1.5 \mathrm{~h} ;(-\cdots) 3 \mathrm{~h} ;(---) 5 \mathrm{~h}$; and (-) $20 \mathrm{~h}$ for normal and type II HANE. The vertical line connects the peak densities of the extracellular protein at the three times of the chase for the normal and at the earliest time in the chase for the type II cells. The curves for the type II cells at 3,5 , and $20 \mathrm{~h}$ are shifted to the right.

under reducing conditions (Fig. 6). The same complex was present in activated $\mathrm{Cls}$-reacted supernatants of cells for normal and for both types of HANE (Fig. 6). Both the decrease in the $102-\mathrm{kD}$ form and the increase in the $125-\mathrm{kD}$ complex paralleled the increase in added $\mathrm{Cls}$; the maximal changes occurred at $1.4 \mu \mathrm{g} / \mathrm{ml}$ added Cls. The amounts of the $94-\mathrm{kD}$ form of $\mathrm{Cl}$ INH (present in all three types of cells in this experiment) decreased when highest concentration of activated $\mathrm{C} 1 \mathrm{~s}$ was added. The fate of the 94-kD C1 INH was not identified on the SDS-PAGE analysis, as neither lower molecular mass forms (not shown) nor an increase in the amount of $125-\mathrm{kD}$ complex was apparent.

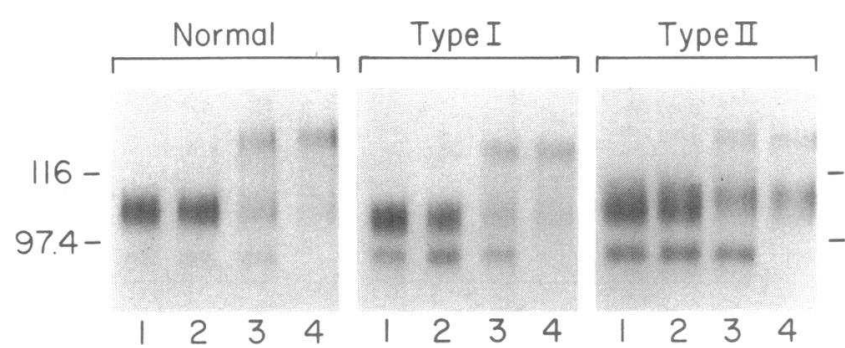

Figure 6. Binding of $\mathrm{C} 1 \mathrm{INH}$ secreted from normal and types I and II HANE fibroblasts to activated C1s. Supernatants after $4 \mathrm{~h}$ of pulse were collected, as described in Methods. Three different concentrations of activated $\mathrm{Cls}$ were added to the aliquots of supernatants of different cell types and incubated for $1 \mathrm{~h}$ at $37^{\circ} \mathrm{C}$. The samples then were immunoprecipitated for $\mathrm{Cl}$ INH. The concentrations of $\mathrm{Cls}$ used were $0 \mu \mathrm{g} / \mathrm{ml}$ (lanes 1 ); $0.14 \mu \mathrm{g} / \mathrm{ml}$ (lanes 2); $1.4 \mu \mathrm{g} / \mathrm{ml}$ (lanes 3 ); and $14.0 \mu \mathrm{g} / \mathrm{ml}$ (lanes 4 ). Molecular mass markers are shown on the left.
Densitometric scanning of the autoradiograms was performed to investigate the relative functional activities of the two forms of $\mathrm{Cl}$ INH secreted by the Ta type II HANE cells (Fig. 7). The symmetrical band of type II C1 INH (102-110 kD) (Fig. 7, peak 2) became asymmetrical after the reaction with activated $\mathrm{Cl}$ s, showing much more nonreacting protein in the higher molecular mass portion of the band. In type I and normal cells, the positions of the peaks remained the same before and after addition of activated C1s, indicating that the $\mathrm{C} 1 \mathrm{INH}$ band contained only one form of protein.

Analysis of C1 INH $\mathrm{mRNA}$ levels in HANE fibroblasts. Two separate analyses were performed. In the first, levels of mRNA were compared in the normal and type I and II HANE cells to determine if differences in the baseline rates of synthesis demonstrated in Figs. 1 and 2 were controlled at a pretranslational level. In the second, effects of gamma-IFN on levels of mRNA in the three cell types were assessed to determine if the $\mathrm{C} 1 \mathrm{INH}$ genes in HANE were regulated in the same manner as in normal.

For the first analysis, levels of mRNA in control (unstimulated) cells for normal and types I and II HANE were compared by densitometric scanning of RNA blots, similar to the one shown in Fig. 8. When compared with levels in a normal line, levels of $\mathrm{Cl}$ INH mRNA for type I lines were $27.4 \pm 6.1 \%$ of normal (mean $\pm \mathrm{SD}, n=5$ ). For type II lines, levels were $122 \pm 33 \%$ of normal $(n=4)$. For both the type I and type II lines, these results were parallel to the results for the levels of protein synthesis in these cells, indicating that the decrease in synthesis of $\mathrm{C} 1 \mathrm{INH}$ in type I HANE was regulated at a pretranslational level.

To study the regulation of $\mathrm{C} 1 \mathrm{INH}$ synthesis in HANE cells by IFN- $\gamma$, the normal and types I and II HANE cells were
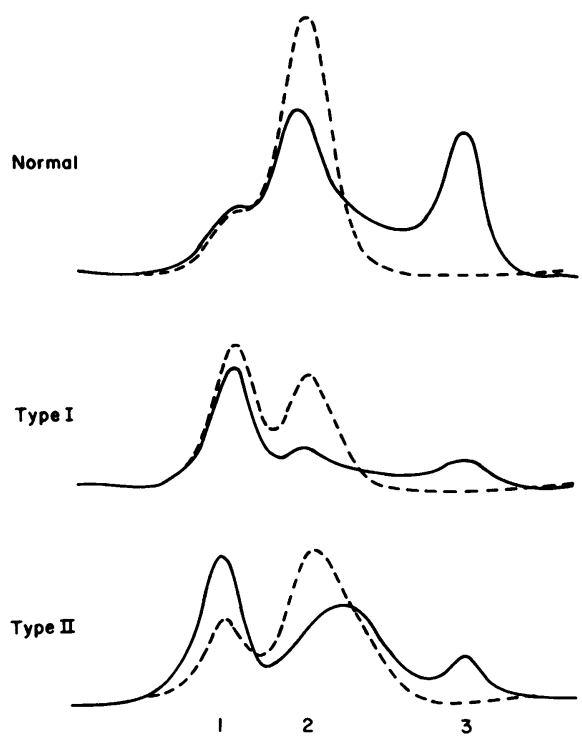

Figure 7. Densitograms of the $\mathrm{Cls}$ binding assay for normal and types I and II HANE fibroblasts. The autoradiograms of lanes for control and optimal concentration of $\mathrm{C} 1 \mathrm{~s}(1.4 \mu \mathrm{g} / \mathrm{ml})$ from Fig. 6 were scanned by laser densitometer. The molecular mass increases from left to right: peak $1=94 \mathrm{kD}$; peak $2=102 \mathrm{kD}$; and peak $3=125$ $\mathrm{kD}$ the complex between $\mathrm{Cl} \mathrm{INH}$ and $\mathrm{Cls}$ under reducing conditions. $(---)$ Control (lanes 1 from Fig. 6), and $(-) 1.4 \mu \mathrm{g} / \mathrm{ml} \mathrm{Cls} \mathrm{added}$ (lanes 3 from Fig. 6). 


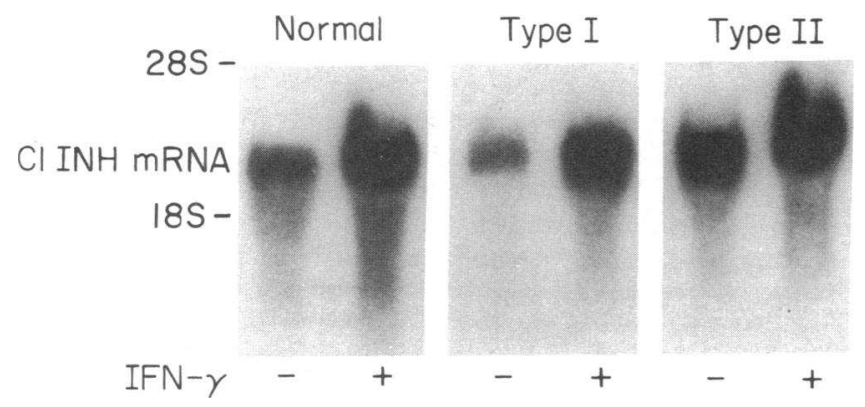

Figure 8. RNA blot analysis of C1 INH mRNA in normal and types I and II HANE fibroblasts. Confluent cells were cultured in medium alone or in medium containing gamma-IFN, $1,000 \mathrm{U} / \mathrm{ml}$, for $24 \mathrm{~h}$, and total RNA was prepared. $10 \mu \mathrm{g}$ of each sample was applied into the agarose gel under denaturing conditions and transferred to nitrocellulose. Ethidium bromide shadowing indicated that equal amounts of total RNA had been loaded into each lane.

incubated with IFN- $\gamma(1,000 \mathrm{U} / \mathrm{ml})$ for $24 \mathrm{~h}$ before synthesis of $\mathrm{C} 1 \mathrm{INH}$ was assessed as described in Methods and in the legend for Fig. 2. IFN- $\gamma$ increased $\mathrm{Cl}$ INH synthesis by 8.0-, 9.3-, and 8.4-fold in normal, type I, and type II cells, respectively. For the type II cells, both the 78 and $86-\mathrm{kD}$ forms of the protein were increased equally (data not shown). In parallel RNA blot analyses (Fig. 8), the increased levels of C1 INH mRNA induced by IFN- $\gamma$ paralleled the increases in protein synthesis, suggesting that the effect of IFN- $\gamma$ on $\mathrm{Cl}$ INH expression in all three types of cells occurred at a pretranslational level.

\section{Discussion}

In this report we have used skin fibroblasts to study rates of synthesis of $\mathrm{Cl}$ INH in patients with both types I and II HANE. We provide definitive evidence that synthesis of $\mathrm{Cl}$ INH in type I HANE is much lower than the $50 \%$ expected from the single normal allele present in this autosomal dominant disorder. The decrease in synthesis of C1 INH in the type I cells appears to be regulated at a pretranslational level. In type II HANE, synthesis of the combination of functional and dysfunctional forms of $\mathrm{C} 1 \mathrm{INH}$ was $\sim 100 \%$ of normal, with the functional protein comprising $43 \%$ of the total. Thus, the functional protein was synthesized at a much higher rate in the type II cells than in the type I cells. The comparison of levels of synthesis in the type I and type II cells suggests that expression of the normal allele is influenced by the type of mutant allele present. The reason that the single $\mathrm{Cl}$ INH allele in type I HANE does not function as well as in normal or type II HANE cells is not understood. Fibroblasts provide an excellent model for the study of the role of the mutant alleles in the expression of the disease phenotype in both type I and type II HANE. Further work will have to be done to determine if the regulation of synthesis in these cells parallels exactly the regulation in hepatocytes, where the majority of the protein is synthesized in vivo.

Regulation of synthesis of $\mathrm{C} 1 \mathrm{INH}$ in fibroblasts appears to be different than regulation in monocytes. This difference is most apparent in the constitutive rate of synthesis, with fibroblasts synthesizing 50-100 times more $\mathrm{Cl}$ INH per cell than monocytes. Results of studies of $\mathrm{Cl}$ INH synthesis in monocytes from patients with type I HANE were also different than in fibroblasts, in that rates of synthesis of C1 INH in the type I patients averaged $40 \%$ of normal, well above the $20 \%$ observed in our studies with fibroblasts. In addition, amounts of $\mathrm{C} 1 \mathrm{INH}$ recovered outside monocytes has been reported to be much lower than the amount synthesized (Cicardi et al. [3] found 24, 18 , and $14 \%$ of normal amounts in the supernatant of three HANE monocytes cultures compared with 43,53 , and $35 \%$ synthesized and present intracellularly in the same cultures). It is possible that these differences in the results with the two cell types represents tissue-specific regulation of $\mathrm{Cl}$ INH synthesis. However, these differences may also be due to the low rates of C1 INH synthesized in monocytes, which would make comparisons between rates of synthesis and secretion in type I HANE and normal inaccurate. For example, Lappin et al. had to culture the monocytes for $7 \mathrm{~d}$ to obtain amounts of $\mathrm{Cl}$ INH that could be measured by ELISA (4). Adequate amounts of $\mathrm{Cl}$ INH were produced by the fibroblasts in less than $24 \mathrm{~h}$. While less likely, it is also possible that the difference in results reflects a heterogeneity in the type I patients, with some patients having the expected $50 \%$ of synthesis and others having much lower rates. Synthesis and secretion of $\mathrm{Cl}$ INH in type II HANE has not been studied previously.

The Cl INH synthesized in both type I and type II HANE fibroblasts was completely secreted and the amounts of extracellular protein paralleled exactly the rates of synthesis. The dysfunctional protein in the type II cells was secreted with only minor delays, unlike the dysfunctional protein in $\alpha 1$-antitrypsin deficiency, another model of genetic disease involving a serum protease inhibitor (20). The cultures of the HANE cells contained the $94-\mathrm{kD} \mathrm{C1} \mathrm{INH}$ form found in serum of patients with HANE (21). In addition, the normal, but not the dysfunctional, $\mathrm{C} 1$ INH protein could bind to activated $\mathrm{Cls}$.

IFN- $\gamma$ increased $\mathrm{Cl}$ INH synthesis in normal and in types I and II HANE cells at a pretranslational level, similar to results in other primary human cell types that have been studied (6-8). The increases in rates of synthesis induced by IFN- $\gamma$ were similar for the dysfunctional and functional $\mathrm{Cl}$ INHs in type II HANE cells. Thus, the interferon response sequences of the $\mathrm{Cl}$ INH genes are intact in both types of HANE.

HANE is a polymorphic disease. Differences occur between serum levels of C1 INH in types I and II HANE. In most type I patients there is no restriction fragment length polymorphism, but deletions in either exon 4 or exon 7 have been identified in some type I kindreds $(3,22,23)$. In type II HANE, mutations occur mostly in the $P 1$ reactive center at amino acid 444 (24), but may also occur at 251 (Ta kindred) (13). Our studies indicate that differences are also present for the rate of synthesis of the normal protein, with a rate of $\sim 20 \%$ of normal in type I compared with almost $50 \%$ in type II. The basis of the decrease in rate of synthesis in type I cells is not known, but may represent an interaction between the normal and abnormal C1 INH alleles in type I HANE.

\section{Acknowledgments}

We thank Dr. Harvey R. Colten for his helpful discussion during the course of these studies, and Dr. John P. Atkinson for help in recruiting the patients with type I hereditary angioneurotic edema.

This work was supported by grants HL-37591, AI-24836, DK26609, and HD-22082 from the National Institutes of Health, and by March of Dimes grant 6-562. 


\section{References}

1. Lachmann, P. J., and F. S. Rosen. 1984. The catabolism of C1-inhibitor and the pathogenesis of hereditary angio-edema. APMIS (Acta Pathol. Microbiol. Immunol. Scand.) Suppl. 284. 92:35-39.

2. Quastel, M., R. Harrison, M. Cicardi, C. A. Alper, and F. S. Rosen. 1983 Behavior in vivo of normal and dysfunctional $\mathrm{Cl}$ inhibitor in normal subjects and patients with hereditary angioneurotic edema. J. Clin. Invest. 71:1041-1046.

3. Cicardi, M., T. Igarashi, F. S. Rosen, and A. E. Davis III. 1987. Molecular basis for the deficiency of complement 1 inhibitor on type I hereditary angioneurotic edema. J. Clin. Invest. 79:698-702.

4. Lappin, D. F., A. R. McPhaden, P. Yap, P. E. Carter, G. D. Birnie, J. E. Fothergill, and K. Whaley. 1989. Monocyte C1-inhibitor synthesis in patients with C1-inhibitor deficiency. Eur. J. Clin. Invest. 19:45-52.

5. Katz, Y., and R. C. Strunk. 1988. Synovial fibroblast-like cells synthesize seven proteins of the complement system. Arthritis Rheum. 31:1365-1370.

6. Katz, Y., and R. C. Strunk. 1989. Synthesis and regulation of $\mathrm{Cl}$ inhibitor in human skin fibroblasts. J. Immunol. 142:2041-2045.

7. Lotz, M., and B. L. Zuraw. 1987. Interferon- $\gamma$ is a major regulator of C1-inhibitor synthesis by human blood monocytes. J. Immunol. 139:3382-3387.

8. Schmaier, A. H., S. C. Murray, G. D. Heda, A. Farber, A. Kuo, K. McCrae, and D. B. Cines. 1989. Synthesis and expression of $C 1$ inhibitor by human umbilical vein endothelial cells. J. Biol. Chem. 264:18173-18179.

9. Rosen, F. S., C. A. Alper, J. Pensky, M. R. Klemperer, and V. H. Donaldson. 1971. Genetically determined heterogeneity of the $\mathrm{Cl}$ esterase inhibitor in patients with hereditary angioneurotic edema. J. Clin. Invest. 50:2143-2149.

10. Gadek, J. E., S. W. Hosea, J. A. Gelfand, and M. M. Frank. 1979. Response of variant hereditary angioedema phenotypes to danazol therapy. Genetic implications. J. Clin. Invest. 64:280-286.

11. Donaldson, V. H., R. A. Harrison, F. S. Rosen, D. H. Bing, G. Kindness, J. Canar, C. J. Wagner, and S. Awad. 1985. Variability in purified dysfunctiona $\mathrm{Cl}$-inhibitor proteins from patients with hereditary angioneurotic edema. Functional and analytical gel studies. J. Clin. Invest. 75:124-132.

12. Donaldson, V. H., C. J. Wagner, B. Tsuei, G. Kindness, D. H. Bing, R. A Harrison, and F. S. Rosen. 1987. Interactions of plasma kallikrein and C1s with normal and dysfunctional $\mathrm{Cl}$-inhibitor proteins from patients with hereditary angioneurotic edema: analytic gel studies. Blood. 69:1096-1101.

13. Parad, R. B., J. Kramer, R. C. Strunk, F. S. Rosen, and A. E. Davis. 1990
Dysfunctional Cl inhibitor (C1 INH) Ta: deletion of Lys-251 results in acquisition of a unique N-glycosylation site. Proc. Natl. Acad. Sci. USA. 87:6786-6790.

14. Cole, F. S., H. S. Auerbach, G. Goldberg, and H. R. Colten. 1985. Tissue specific pretranslational regulation of complement production in human mononuclear phagocytes. J. Immunol. 134:2610-2616.

15. Katz, Y., F. S. Cole, and R. C. Strunk. 1988. Synergism between $\gamma$ interferon and lipopolysaccharide for synthesis of factor $\mathrm{B}$, but not $\mathrm{C} 2$, in human fibroblasts. J. Exp. Med. 167:1-14.

16. Strunk, R. C., F. S. Cole, D. H. Perlmutter, H. R. Colten, 1985, Gammainterferon increases expression of class III complement genes $\mathrm{C} 2$ and factor $\mathrm{B}$ in human monocytes and in murine fibroblasts transfected with human C2 and factor B genes. J. Biol. Chem. 260:15280-15285.

17. Falus, A., H. Rokita, E. Waltz, M. Brozik, T. Hidvegi, and K. Meretey 1990. Hormonal regulation of complement biosynthesis in human cell lines - II. Upregulation of the biosynthesis of complement components $\mathrm{C} 3$, factor $\mathrm{B}$ and $\mathrm{C}$ inhibitor by interleukin-6 and interleukin-1 in human hepatoma cell line. Mol. Immunol. 27:197-201.

18. Chirgwin, J. M., A. E. Przybyla, R. J. MacDonald, and W. J. Rutter. 1979. Isolation of biologically active ribonucleic acid from sources enriched in ribonuclease. Biochemistry. 18:5294-5299.

19. Cicardi, M., T. Igarashi, M. S. Kim, D. Frangi, A. Agostini, and A. E. Davis III. 1987. Restiction fragment length polymorphism of the $\mathrm{Cl}$ inhibitor gene in hereditary angioneurotic edema. J. Clin. Invest. 80:1640-1643.

20. Perlmutter, D. H., G. I. Glover, M. Rivetna, C. S. Schasteen, and R. J. Fallon. 1990. Identification of a serpin-enzyme complex (SEC) receptor on human hepatoma cells and human monocytes. Proc. Natl. Acad. Sci. USA. 87:3753-3759.

21. Zuraw, B. L., and J. G. Curd. 1986. Demonstration of modified inactive first component of complement $(\mathrm{Cl})$ inhibitor in the plasmas of $\mathrm{Cl}$ inhibitor-deficient patients. J. Clin. Invest. 78:567-575.

22. Stoppa-Lyonnet, D., M. Tosi, J. Laurent, A. Sobel, G. Lagrue, and T. Meo. 1987. Altered $\mathrm{Cl}$ inhibitor genes in type I hereditary angioedema. $N$. Engl. J. Med. 317:1-6.

23. Ariga, T., T. Igarashi, N. Ramesh, R. Parad, M. Cicardi, and A. E. Davis III. 1989. Type I Cl inhibitor deficiency with a small messenger RNA resulting from deletion of one exon. J. Clin. Invest. 83:1888-1893.

24. Aulak, K. S., P. A. Pemberton, F. S. Rosen, R. W. Carrell, P. J. Lachmann, and R. A. Harrison. 1988. Dysfunctional C1-inhibitor (At), isolated from a type II hereditary angioneurotic edema plasma, contains a P1 'reactive centre' (Arg444/ His) mutation. Biochem. J. 253:615-618. 